Vol. 1, Issue. 1 | January - June 2021

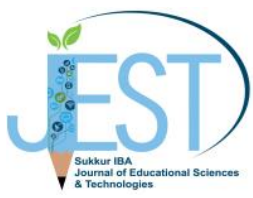

\title{
An Investigation of the Teaching Techniques, Assessment Strategies and Students' Attitude towards Reading English and their Impact on Learners' Performance in Pakistan
}

\author{
Dr. Allahdino Abro ${ }^{1}$, Dr. Ghulam Rasool Soomro ${ }^{2}$, Dr. Roshan Ali Teevno ${ }^{3}$ \\ ${ }^{1}$ Muhammad Bux Shoro Higher Secondary School Hyderabad \\ ${ }^{2}$ Comprehensive Higher Secondary School Hyderabad \\ ${ }^{3}$ Begum Nusrat Bhutto Women University Sukkur \\ Corresponding author‘s email: ada2000@live.com
}

\begin{abstract}
Effective teaching learning of English has got a prominent position in all the educational plans and policies of Pakistan. To ensure the effectiveness of English, efforts have been taken to enhance the teaching learning strategies, assessment techniques and reading attitude of students. Considering the importance of English, a survey, regarding the teaching techniques, assessment strategies and learners' reading attitude and their impact on learners' performance, has been conducted. The sample, comprising 535 students and 26 teachers, from target population delimited to Hyderabad, had been selected using random stratified technique of sampling. The findings clarified that earners' reading attitude, assessment strategies and teaching techniques (independent variables) were strongly correlated to the performance of learners. However, the poor performance of students in English raised a question on assessment strategies, teaching techniques and learners' attitude. The teachers and students mutually perceived that conservative and unproductive teaching and assessment techniques employed by higher secondary school teachers failed to attract and motivate the students in order to enhance their performance. Even the teachers having vast teaching experience were incapable to use modern techniques and AV aids in their classroom teaching and assessment. They were incapable to develop and employ the modern standardized assessment tests. Rather than to focus on learners' skill development, teachers focused on memorization and rote learning. Consequently, students' interest toward classroom learning process did not flourish. Their attitude towards learning English was not praiseworthy. The research paper is rounded off with suggestions at the end.
\end{abstract}

Keywords: The teachers' teaching techniques, teachers' assessment strategies, students' reading attitude and performance in English subject.

\section{Introduction}

Globalization has brought many changes all over the world. The rapid change in technology has made the world a global village, where people from every nook and corner can easily exchange their goods and services. They can share their knowledge, experience, skills and other social, cultural, political and commercial activities. For the global communication, they have selected a language (English) which is universally accepted as a lingua franca. In this regard Erkan (2005) points out that without learning English, one cannot be the part of global village. Learning English is basic requirement for the survival in the global village (p. 14). Most of the world knowledge regarding education, health, economics, technology, trade, management and politics etc. is in English. Crystal (1997) affirms that 80\% world knowledge is found in English. Without learning English one cannot gain modern and latest knowledge about science, technology, research and education etc. Paik (as cited in Nawab, 2012) describes that the world, quickly, realized the importance of English when its use as a global medium of communication became common. Doing a successful global business - import and export without fluency in English language is not easy. English is the basic requirement to remain alive in the global business. Currently, the survival of developing countries, in the world economy without English, is considered almost impossible in the tough global competition.

Pakistan, being a developing country, is also actively participating in the race of acquiring English. Effective teaching learning of English is kept at top priority in all the educational policies and plans of Pakistan. 
Government is taking all the possible measures to raise the standard of English in Pakistan. Pakistani students, realizing the need and importance, are doing their best to acquire the fluency in English.

The students might have realized that fluency in English is the only key to success in the global competition. The candidates having command over their subject are often rejected due to English deficiency. Getting a job or admission in a recognized institution without English proficiency is very difficult. In this regard Coleman (2010) affirms that getting a government job is not easy for candidates having no command over English. It is famous for playing "a gate keeping role" (p. 3). The demand of English is increasing day by day at local, national and international level. Consequently, Pakistan students have kept the English proficiency in their priorities at top. Pinon and Haydon (2010) admit that students who are very careful about their career are eager to improve their English skills.

Acquiring English skills is not as difficult as is found in Pakistani educational organization. In Pakistani educational organizations less focus is given on basic skills of English. Coleman (2010) not only criticizes teaching learning of English in Pakistan but also calls it ineffective and unproductive. To him, neither teachers are committed and competent nor are students interested in learning the basic skills of English. The teachers and students rather than to focus on the teaching learning of basic skills of English, put all their efforts in completing the course in such a way that students may pass their annual examination with flying colour.

Coleman (2010) further asserts that when majority of teachers do not have command over basic learning skills of English, how they can teach these skills effectively to students. Rather than to develop and promote reading, writing, speaking and listening skills, both teachers and students try their level best to complete the contents of book so that students may secure more marks in the examination in the English paper. They teach only selected parts of the book. In this way teachers teach only half course and students learn only half of that half course without proper understanding and comprehension. Consequently, students' knowledge, vocabulary, academic performance and English proficiency skills are negatively affected due to defected teaching and learning process, taking place in most of the Pakistani educational institutions.

Pakistan government in collaboration with Society of Pakistan English Language, Aga Khan University and British council has tried level best to make the professional training of English teachers but result still is dismal. Kasi (2010) confirms that teacher training programs of Pakistan neither transmit knowledge nor develop professional English language skills. In most of the teacher education institutions no focus has been given on modern and latest teaching and assessment techniques. Consequently, teachers coming out of teacher educational institutions also teach and assess their students using the classical, conservative and traditional techniques. They are not so much competent to motivate and attract the students towards learning English. As a result, students also pay less attention on the basic skills of English. Considering the need and importance of effectiveness of teaching learning of English, a research regarding the effectiveness of English teaching techniques, assessment strategies and learners' reading attitude and their impact on learners' performance has been conducted.

\subsection{Research questions}

- RQ1. To what extent is there the impact of teaching techniques on students' performance intermediate level in Pakistan?

- RQ2. To what extent is there the impact of assessment strategies on students' performance at intermediate level in Pakistan?

- RQ3. To what extent is there the impact of students' reading attitude on their performance at intermediate level in Pakistan?

- RQ4. What is the difference of perceptions between students and teachers regarding students' reading attitude, teachers' teaching techniques and assessment strategies?

\subsection{Hypothesis}

- Ho. There is no significant impact of teachers' teaching techniques on students' performance at intermediate level.

- Ho. There is no significant impact of teachers' assessment strategies on students' performance at intermediate level.

- Ho. There is no significant impact of students' reading attitude on their performance at intermediate level. 
- Ho. There is no significant different of perception between students and teachers regarding students' reading attitude, teachers' teaching techniques and assessment strategies at intermediate level.

\section{Review of Literature}

English, having got the status of international medium of communication, is universally accepted as the language of science, technology, economics, industry, trade, education etc all over the world. English has been introduced as a compulsory subject in all the Pakistani educational institutions from class one to class B.A (class 14). In the same way, English language is being used as the medium of instruction by the most schools of Pakistan. Additionally, the official language of Pakistan is English and getting charming jobs without English proficiency is not possible for Pakistani youth. According to Ghani, Mahmood and Akram (2008), the teaching learning of English is compulsory in Pakistan. In addition, being secondary language, English has been given the status of official in Pakistan.

The teaching and learning process of English language in most of the Pakistani educational institutions is not satisfactory. Showing his disappointment Khan (2011) describes that despite of the development of several education policies for the enhancement of education, the condition of English teaching learning is still alarmingly poor. Likewise, Khan and Pandian (2011) also believe that "Pakistani system of education is being criticized not only by policy makers and educationists but also by Pakistani Government" (p. 4). Giving the reference of Ministry of education (as cited in Khan \& Pandian, 2011), "they have ranked the education system of Pakistan as the most deprived, having lower standard in Asia" (p. 4). Nawab (2012) depicting the picture of common observation stresses that students especially rural areas having got B.A degree are unable to read, write, listen and speak English correctly (p. 696). Criticizing English teaching learning in Pakistan Janjua, Malik and Rahman (2011) assert that the English proficiency of students in Pakistan is very miserable (p. 1362)

The Standard of English in most of the schools is very deplorable in every nook and corner of Pakistan. In this regard Warsi (as cited in Khan \& Pandian, 2011) describes that English in Pakistani Schools, being subjective, encompasses only knowledge. Understanding and performance is mostly ignored in this regard. Similarly, Shah, Farooq, Shah and Shams (2010) also point out that our students, having command over their subject, are embarrassed due to English deficiency (p. 108).

Learning English as second language is not as difficult as it is considered in Pakistan Effective teaching learning of English is based on four basic skills (listening, reading, speaking \& writing). Until and unless students are not taught these basic skills using modern teaching techniques and latest assessment strategies, the learners' motivation will not take place, consequently learners will not pay attention. Learning of English without paying attention is not more than wasting precious time and energy of students.

Due to lack of emphasis on the motivation of students towards basic skills, the teaching learning has not achieved the standard acceptable at national and international level. No doubt serious efforts have been taken on the part of government during the last few decades but all these efforts are limited to changing policies and modifying curriculum but implementation of policies and curriculum remained practically neglected. Teachers and students, still following the old and outdated tradition, focus merely on passing the examination rather than learning the basic skills. Consequently, students pass only examination and get the degree but not English proficiency. Criticizing education system khan (2011) points out that examination seems to occupy the prominent position in Pakistani education system where memorization supersedes to learning. Examination centered approach leads students to memorization rather than learning (p. 58). Adding to this Warsi (2004) believes that teaching of English is not directly proportional to learning of English. Teaching English using old and out dated teaching techniques adds nothing to learning. Nunan (1988) showing his dissatisfaction with teaching learning system states that teaching English does not support the development of basic skills of English.

Students often face lot of problems while reading lengthy passages due to students' deficiency of reading skills (Kashef, Viyani, Ghabool \& Damavand, 2012, p.58). Adding to this Khand (2004) describes that deficiency in reading skills and comprehension capability is reflected in students' poor performance in every walk of life. Due to this deficiency professional career of students remains unstable.

To sum up, English is basic requirement for the successful professional careers of students. Learning of English without learning basic skills is not easy. Learning of basic skills of English especially reading skill is direct proportionally related to the effectiveness of teaching techniques, assessment strategies and learners' reading attitude. 


\section{Methodology}

The methodology adapted in this study is survey because now a day survey shows more accuracy, consistency, flexibility, reliability and is being used widely in education all over the world. Supporting survey DeMarraiss and Lapan (2004) describe that survey is widely used in building theories, making planning and decisions in different organizations (p. 284). Adding to this Creswell (2008) asserts that since many years survey is being widely used in education especially for analyzing perceptions, attitudes and beliefs (p. 388). In survey, mostly large population can easily be sampled and information can also be generalized to larger population with consuming less time, money and energy (Cohen \& Lea, 2005, p. 151). Sapsford (as cited in Gray, 2004) narrates that survey presents a population map and leads to systematic collection of data from the population (p. 99). Gray (2004), Neuman (2007) and Fink (1995) also appreciate the practical application of survey in different fields. To them survey is the most effectively used method in all the fields.

However, for this survey, the sample was delimited to male, female and mix higher secondary schools of Hyderabad region. Through random stratified sampling technique, a sample of five hundred thirty five students and twenty six teachers was selected. Additionally, B.I.S.E. result (performance) of students in English was also obtained to make comparison in this regard.

Using SPSS-22, the data were analyzed. ANNOVA (regression) test was used to measure the impact of independent variables (teaching techniques, assessment strategies and students' attitude) on dependent variable (students' performance). Also, t-test was used to assess the difference in the perceptions between teachers and students.

Findings

TABLE I. Item-wise analysis

\begin{tabular}{|c|c|c|c|c|c|c|c|}
\hline S\# & \multicolumn{2}{|l|}{$\begin{array}{l}\text { Students } n=535 \\
\text { Teachers } n=26\end{array}$} & $\begin{array}{l}\text { SD } \\
(\%)\end{array}$ & $\begin{array}{l}\text { D } \\
(\%)\end{array}$ & $\begin{array}{l}\text { UD } \\
(\%)\end{array}$ & $\begin{array}{l}\mathrm{A} \\
(\%)\end{array}$ & $\begin{array}{l}\text { SA } \\
(\%)\end{array}$ \\
\hline & \multirow{2}{*}{$\begin{array}{l}\text { The teaching techniques employed by teachers } \\
\text { at enhance the performance of learners. }\end{array}$} & Students & 20.7 & 37.4 & 1.9 & 20.4 & 19.6 \\
\hline & & Teachers & 42.3 & 15.4 & 3.8 & 3.8 & 34.6 \\
\hline & \multirow[t]{2}{*}{ The teachers use modern techniques. } & Students & 26.5 & 40.7 & 0.4 & 21.9 & 10.5 \\
\hline & & Teachers & 61.5 & 15.4 & 7.7 & 3.8 & 11.5 \\
\hline & \multirow[t]{2}{*}{ The teachers use A.V aids. } & Students & 69.7 & 15.7 & 0.6 & 8.2 & 5.8 \\
\hline & & Teachers & 50 & 30.8 & 3.8 & 7.7 & 7.7 \\
\hline & \multirow{2}{*}{ The teachers employ reading activity daily. } & Students & 26.2 & 33.3 & 1.1 & 21.5 & 17.9 \\
\hline & & Teachers & 15.4 & 3.8 & 3.8 & 15.4 & 61.5 \\
\hline & \multirow{2}{*}{$\begin{array}{l}\text { The teachers themselves read the lesson before } \\
\text { asking students to read. }\end{array}$} & Students & 21.7 & 23.6 & 0.9 & 23.6 & 30.3 \\
\hline & & Teachers & 3.8 & 3.8 & 3.8 & 7.7 & 80.8 \\
\hline & \multirow{2}{*}{$\begin{array}{l}\text { The teachers ask the students one by one to } \\
\text { read in the class. }\end{array}$} & Students & 23.4 & 19.3 & 1.1 & 39.8 & 16.4 \\
\hline & & Teachers & 3.8 & 7.7 & 3.8 & 46.2 & 38.5 \\
\hline & \multirow{2}{*}{$\begin{array}{l}\text { The teachers guide the students during } \\
\text { reading. }\end{array}$} & Students & 17 & 22.4 & 1.1 & 35.1 & 24.3 \\
\hline & & Teachers & 11.5 & 00 & 7.7 & 11.5 & 69.2 \\
\hline & \multirow{2}{*}{$\begin{array}{l}\text { The teachers highlight grammar during } \\
\text { reading. }\end{array}$} & Students & 22.6 & 39.6 & 0.9 & 18.5 & 18.3 \\
\hline & & Teachers & 15.4 & 3.8 & 3.8 & 11.5 & 65.4 \\
\hline & \multirow{3}{*}{$\begin{array}{l}\text { The teachers allow the students to check new } \\
\text { words in the dictionary while reading. }\end{array}$} & Students & 39.8 & 39.1 & 0.9 & 13.3 & 6.9 \\
\hline & & Teachers & 50 & 7.7 & 11.5 & 3.8 & 26.9 \\
\hline & & Students & 13.5 & 42.4 & 3.4 & 19.4 & 21.3 \\
\hline
\end{tabular}


$\begin{array}{lllllll}\text { The teachers teach students how to read lesson } & \text { Teachers } & 53.8 & 15.4 & 3.8 & 7.7 & 19.2\end{array}$ quickly to get its central theme.

$\begin{array}{lllllll}\text { The teachers teach students how to read lesson } & \text { Students } & 35.7 & 26.4 & 2.1 & 9.7 & 26.2\end{array}$

deeply to understand it thoroughly.

$\begin{array}{llllll}\text { Teachers } & 46.2 & 26.9 & 7.7 & 7.7 & 11.5\end{array}$

$\begin{array}{lllllll}\text { The teachers teach students how to analyze } & \text { Students } & 40.2 & 39.1 & 2.4 & 3.2 & 15.1\end{array}$

lesson critically after reading.

$\begin{array}{llllll}\text { Teachers } & 46.2 & 26.9 & 3.8 & 11.5 & 11.5\end{array}$

$\begin{array}{lllllll}\text { The teachers teach students how to summarize } & \text { Students } & 20.7 & 45.8 & 1.3 & 16.4 & 15.7\end{array}$

lesson after reading.

$\begin{array}{llllll}\text { Teachers } & 19.2 & 50 & 3.8 & 11.5 & 15.4\end{array}$

$\begin{array}{lllllll}\text { The teachers encourage the students to read } & \text { Students } & 14.8 & 26.5 & 0.7 & 25.8 & 32.1\end{array}$

books other than course.

$\begin{array}{llllll}\text { Teachers } & 15.4 & 3.8 & 3.8 & 50 & 26.9\end{array}$

$\begin{array}{lllllll}\text { The teachers encourage the weak students } & \text { Students } & 14.4 & 23.9 & 1.9 & 20.9 & 38.9\end{array}$

during reading activity.

$\begin{array}{llllll}\text { Teachers } & 11.5 & 3.8 & 7.7 & 42.3 & 34.6\end{array}$

$\begin{array}{lllllll}\text { The teachers observe and point out reading } & \text { Students } & 18.5 & 15.7 & 0.7 & 38.3 & 26.7\end{array}$

problems of students.

$\begin{array}{llllll}\text { Teachers } & 00 & 7.7 & 3.8 & 15.4 & 73.1\end{array}$

$\begin{array}{lllllll}\text { The teachers solve the reading problems of } & \text { Students } & 28.8 & 43.2 & 1.1 & 11.2 & 15.7\end{array}$

students.

$\begin{array}{llllll}\text { Teachers } & 15.4 & 3.8 & 7.7 & 11.5 & 61.5\end{array}$

$\begin{array}{lllllll}\text { The reading assessment practice is effective to } & \text { Students } & 21.5 & 45 & 3.4 & 15.5 & 14.6\end{array}$

enhance the performance of learners.

$\begin{array}{llllll}\text { Students } & 21.5 & 45 & 3.4 & 15.5 & 14.6\end{array}$

$\begin{array}{lllllll}\text { The assessment practice is essential for the } & \text { Students } & 15 & 15.3 & 1.7 & 24.3 & 43.7\end{array}$

measurement of the performance of learners.

$\begin{array}{llllll}\text { Teachers } & 15.4 & 7.7 & 7.7 & 26.9 & 42.3\end{array}$

$\begin{array}{llllllll}\text { The teachers prepare and follow reading } & \text { Students } & 32.5 & 38.1 & 1.1 & 16.8 & 11.4\end{array}$ assessment schedule.

$\begin{array}{llllll}\text { Teachers } & 42.3 & 15.4 & 7.7 & 3.8 & 30.8\end{array}$

$\begin{array}{lllllll}\text { The teachers use benchmark books or passages } & \text { Students } & 21.9 & 51.2 & 1.3 & 13.8 & 11.8\end{array}$

to assess students' reading level.

$\begin{array}{llllll}\text { Teachers } & 46.2 & 23.1 & 3.8 & 7.7 & 19.2\end{array}$

$\begin{array}{lllllllll}\text { The teachers use different modern tests } & \text { Students } & 29.9 & 37.6 & 0.7 & 19.1 & 12.7\end{array}$

designed for the assessment of reading.

$\begin{array}{llllll}\text { Teachers } & 42.3 & 11.5 & 3.8 & 19.2 & 23.1\end{array}$

$\begin{array}{llllllll}\text { The teachers use computer or other audio } & \text { Students } & 36.6 & 40.2 & 4.5 & 10.7 & 8\end{array}$

visual aids for the assessment of reading level.

$\begin{array}{llllll}\text { Teachers } & 57.7 & 15.4 & 3.8 & 7.7 & 15.4\end{array}$

$\begin{array}{llllllll}\text { The teachers make audio recording of the } & \text { Students } & 31.6 & 46.7 & 3.7 & 10.3 & 7.7\end{array}$

reading of students and compare it from time

to time to identify the improvement.

$\begin{array}{llllll}\text { Teachers } & 69.2 & 15.4 & 3.8 & 3.8 & 7.7\end{array}$

$\begin{array}{lllllll}\text { The teachers call the experts from time to time } & \text { Students } & 37.6 & 40.4 & 0.4 & 10.7 & 11\end{array}$

to assess the reading level of students.

$\begin{array}{llllll}\text { Teachers } & 42.3 & 19.2 & 3.8 & 11.5 & 23.1\end{array}$

$\begin{array}{llllllll}\text { The teachers arrange reading assessment } & \text { Students } & 38.5 & 53.3 & 0.9 & 3.2 & 4.1\end{array}$

competitions among students of various schools.

$\begin{array}{llllll}\text { Teachers } & 53.8 & 30.8 & 3.8 & 3.8 & 7.7\end{array}$

\begin{tabular}{lllllll} 
The teachers prepare and maintain reading & Students & 41.3 & 36.1 & 3 & 15.1 & 4.5 \\
\cline { 2 - 7 } assessment progress chart of students. & Teachers & 42.3 & 26.9 & 3.8 & 7.7 & 19.2 \\
\hline & Students & 22.4 & 36.3 & 1.1 & 25.8 & 14.4
\end{tabular}




\begin{tabular}{|c|c|c|c|c|c|c|}
\hline $\begin{array}{l}\text { The students / teachers are satisfied with } \\
\text { reading attitude of students at higher } \\
\text { secondary school level. }\end{array}$ & Teachers & 65.4 & 11.5 & 3.8 & 3.8 & 15.4 \\
\hline \multirow{2}{*}{$\begin{array}{l}\text { The reading attitude of learners is essential for } \\
\text { the enhancement of their performance. }\end{array}$} & Students & 7.5 & 7.1 & 0.7 & 51.4 & 33.3 \\
\hline & Teachers & 7.7 & 7.7 & 00 & 26.9 & 57.7 \\
\hline \multirow[t]{2}{*}{ The students try to avoid reading in the class. } & Students & 19.3 & 25.4 & 1.5 & 39.6 & 14.2 \\
\hline & Teachers & 19.2 & 11.5 & 3.8 & 19.2 & 46.2 \\
\hline \multirow{2}{*}{$\begin{array}{l}\text { The students pass their spare time in reading } \\
\text { books. }\end{array}$} & Students & 18.5 & 43.9 & 2.8 & 15.7 & 19.1 \\
\hline & Teachers & 46.2 & 26.9 & 3.8 & 3.8 & 19.2 \\
\hline \multirow[t]{2}{*}{ The students like reading in English. } & Students & 28 & 40 & 0.9 & 12.3 & 18.7 \\
\hline & Teachers & 38.5 & 23.1 & 7.7 & 11.5 & 19.2 \\
\hline \multirow[t]{2}{*}{ The students enjoy reading course books. } & Students & 39.4 & 26.7 & 3 & 10.1 & 20.7 \\
\hline & Teachers & 57.7 & 19.2 & 3.8 & 3.8 & 15.4 \\
\hline \multirow{2}{*}{$\begin{array}{l}\text { The students read more than course books with } \\
\text { interest. }\end{array}$} & Students & 38.1 & 38.3 & 2.8 & 11.4 & 9.3 \\
\hline & Teachers & 42.3 & 11.5 & 11.5 & 7.7 & 26.9 \\
\hline \multirow[t]{2}{*}{ The students like to go to library for reading. } & Students & 37.2 & 29.9 & 1.1 & 9 & 23 \\
\hline & Teachers & 46.2 & 26.9 & 3.8 & 3.8 & 19.2 \\
\hline
\end{tabular}

Analysis: The majority of respondents, as shown in the table-1, perceived that teaching techniques applied by higher secondary teachers in higher secondary schools did not enhance the performance of students in English subject. The teaching techniques were very old and out dated. There was no use of audio-visual aids and latest technology in the classroom teaching of English to enhance students' performance. No doubt teachers used to ask every student to read in the class and guide them during reading but due to lack of use of technology and modern activities, the performance of students was not praiseworthy. Similarly, the students were no allowed to use dictionaries during reading. Moreover, the teachers did not teach them quick reading, deep reading and critical reading techniques. Consequently, the students were not capable to summarize the lessons. There was no motivation and brainstorming regarding reading the prescribed course and other books. However, the students and teachers were divided on "teaching of grammar and problems of students". The students perceived that neither teaching of grammar was satisfactory nor the problems of students, especially weak students, were handled properly, while teachers had perceived differently.

The majority of respondents also perceived that reading assessment techniques, being essential for teaching learning English, did not promote students' performance in English subject. The teachers neither prepared and followed reading assessment schedule nor used the benchmark books or passages to assess the students' reading level. They did not use different tests designed for the assessment of reading. There was no use of computer or latest technology assisted audio visual aids for the assessment of students. The audio recording of reading, preparing and maintaining reading assessment progress chart of students, holding reading assessment competitions among students and calling the experts to assess the performance of students did not exist over there.

To most of the respondents, the reading attitude of students, being very essential to enhance the performance of students in English, was not satisfactory. Most of the students used to avoid going to library for reading English books. The books of English were boring for them and they did not like reading course and other English books. 


\section{Results and Discussion}

TABLE II. Result of hypothesis one

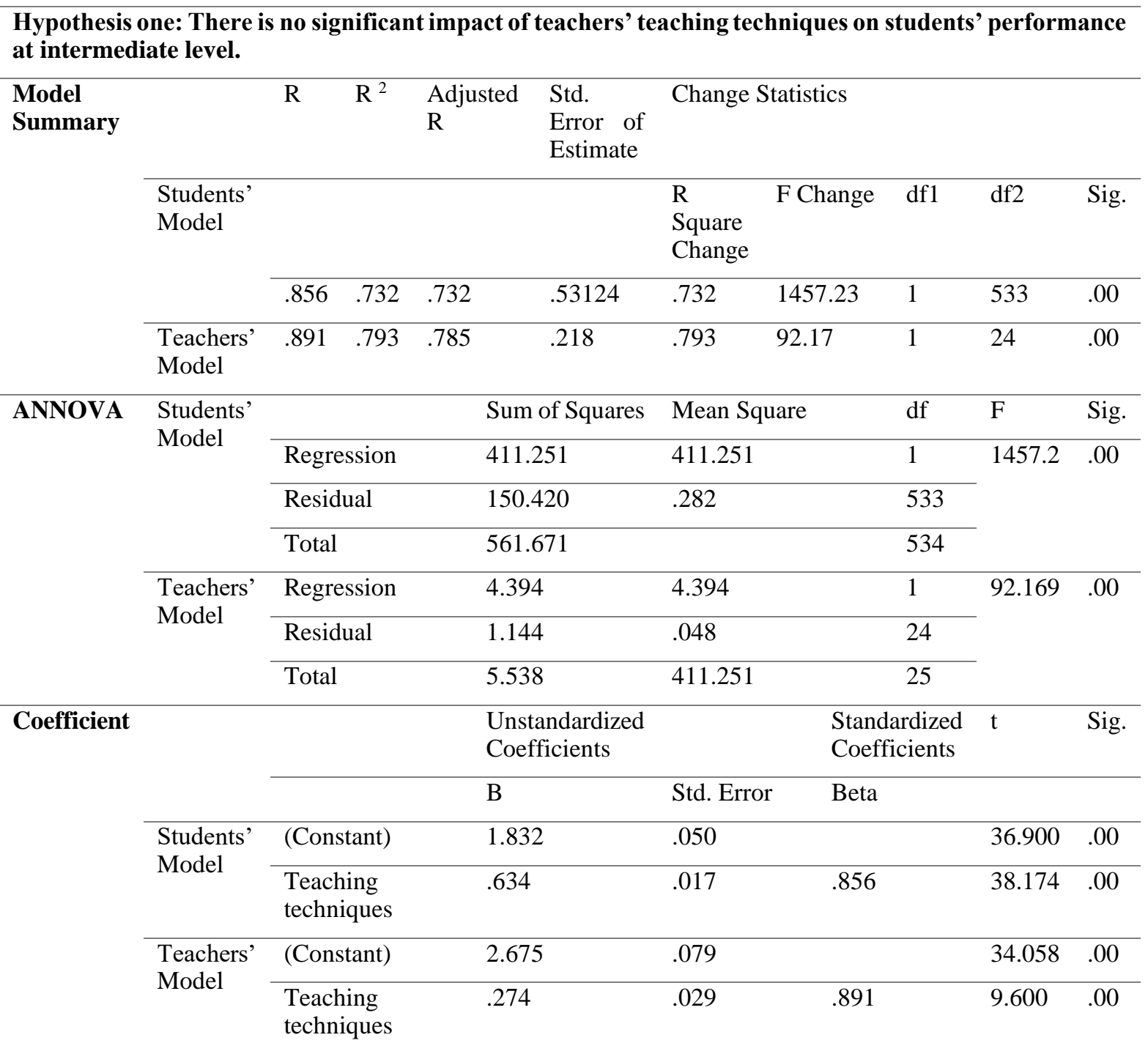

Analysis: The result from the perspective of students and teachers as shown in table-2 reveal that there is significant impact of teaching techniques on students' performance because the independent variable (teaching techniques) and dependent variable (students' performance) are very strongly (students: $p=000$, $\mathrm{r}=.856$ \& teachers: $\mathrm{p}=000, \mathrm{r}=.891$ ) correlated. Likewise, the independent variable (teaching techniques) is very strong predictor of dependent variable (students' performance) because the contribution of R2 is $73.2 \%$ from students' perspective and $79.3 \%$ from teachers' perspective. Moreover, the prediction of students' performance can be made from teaching techniques because the model (F-value) for the prediction of dependent variable (students' performance) from independent variable (teaching techniques) is also significant (students: $\mathrm{p}=000, \mathrm{~F}=1457.2 \&$ teachers: $\mathrm{p}=000, \mathrm{~F}=92.169$ ). In addition, it can be predicted that changes in dependent variable (students' performance) occur due to changes in independent variable (teaching techniques) because value of $\mathrm{t}$ (students: $\mathrm{p}=000, \mathrm{t}=38.174$ \& teachers: $\mathrm{p}=000, \mathrm{t}=9.600$ ) is also significant.

To sum up, the result of model summary $\left(R \& R^{2}\right)$, ANNOVA and coefficient from the perspective of students and teachers for hypothesis-1 reveals that null hypothesis is rejected and alternative is upheld. Hence, it is concluded that there is significant impact of teaching techniques on students' performance in 
English. If an improvement in teaching techniques takes place, it will improve the performance of students as well.

TABLE III. Result of hypothesis two Hypothesis Two: There is no significant impact of teachers' assessment strategies on students'
performance at intermediate level.

\begin{tabular}{|c|c|c|c|c|c|c|c|c|c|c|}
\hline \multirow{4}{*}{$\begin{array}{l}\text { Model } \\
\text { Summary }\end{array}$} & & \multirow{2}{*}{\multicolumn{2}{|c|}{$\mathrm{R}^{2}$}} & \multirow{2}{*}{$\begin{array}{l}\text { Adjusted } \\
\mathrm{R}\end{array}$} & \multirow{2}{*}{$\begin{array}{l}\text { Std. } \\
\text { Error of } \\
\text { Estimate }\end{array}$} & \multicolumn{5}{|c|}{ Change Statistics } \\
\hline & \multirow[t]{2}{*}{$\begin{array}{l}\text { Students' } \\
\text { Model }\end{array}$} & & & & & $\begin{array}{l}\mathrm{R} \\
\text { Square } \\
\text { Change }\end{array}$ & $\begin{array}{l}\text { F } \\
\text { Change }\end{array}$ & df1 & df 2 & Sig. \\
\hline & & .917 & .841 & .840 & .40969 & .841 & 2813.32 & 1 & 533 & .00 \\
\hline & $\begin{array}{l}\text { Teachers' } \\
\text { Model }\end{array}$ & .843 & .711 & .699 & .258 & .711 & 59.092 & 1 & 24 & .00 \\
\hline \multirow[t]{7}{*}{ ANNOVA } & \multirow{4}{*}{$\begin{array}{l}\text { Students' } \\
\text { Model }\end{array}$} & & & \multicolumn{2}{|c|}{ Sum of Squares } & \multicolumn{3}{|c|}{ Mean Square } & $\mathrm{F}$ & Sig. \\
\hline & & \multicolumn{2}{|c|}{ Regression } & \multicolumn{2}{|c|}{472.208} & \multicolumn{2}{|l|}{472.208} & 1 & 2813.33 & .00 \\
\hline & & \multicolumn{2}{|c|}{ Residual } & \multicolumn{2}{|c|}{89.463} & \multicolumn{2}{|l|}{.168} & 533 & & \\
\hline & & \multicolumn{2}{|c|}{ Total } & \multicolumn{2}{|c|}{561.671} & & & 534 & & \\
\hline & \multirow{3}{*}{$\begin{array}{l}\text { Teachers' } \\
\text { Model }\end{array}$} & \multicolumn{2}{|c|}{ Regression } & \multicolumn{2}{|l|}{3.939} & \multicolumn{2}{|l|}{3.939} & 1 & 59.02 & .00 \\
\hline & & \multicolumn{2}{|c|}{ Residual } & \multicolumn{2}{|l|}{1.600} & \multicolumn{2}{|l|}{.067} & 24 & & \\
\hline & & \multicolumn{2}{|c|}{ Total } & \multicolumn{2}{|l|}{5.538} & & & 25 & & \\
\hline \multirow[t]{6}{*}{ Coefficient } & \multirow[t]{4}{*}{$\begin{array}{l}\text { Students' } \\
\text { Model }\end{array}$} & & & \multicolumn{2}{|c|}{$\begin{array}{l}\text { Unstandardized } \\
\text { Coefficients }\end{array}$} & & \multicolumn{2}{|c|}{$\begin{array}{l}\text { Standardized } \\
\text { Coefficients }\end{array}$} & $\mathrm{t}$ & Sig. \\
\hline & & & & \multicolumn{2}{|l|}{ B } & Std. Err & \multicolumn{2}{|l|}{ Beta } & & \\
\hline & & \multicolumn{2}{|c|}{ (Constant) } & \multicolumn{2}{|l|}{1.340} & .045 & & & 30.02 & .00 \\
\hline & & $\begin{array}{l}\text { Asse } \\
\text { strate }\end{array}$ & $\begin{array}{l}\text { sment } \\
\text { gies }\end{array}$ & .697 & & .013 & .917 & & 53.04 & .00 \\
\hline & Teachers' & (Con & $\tan t)$ & 2.479 & & .119 & & & 20.82 & .00 \\
\hline & Moder & $\begin{array}{l}\text { Asse } \\
\text { strate }\end{array}$ & $\begin{array}{l}\text { sment } \\
\text { gies }\end{array}$ & .271 & & .035 & .843 & & 7.69 & .00 \\
\hline
\end{tabular}

Analysis: The result from the perspective of students and teachers as shown in table- 3 reveal that there is significant impact of assessment strategies on students' performance because the independent variable (assessment strategies) and dependent variable (students' performance) are very strongly (students: $\mathrm{p}=000$, $\mathrm{r}=.971 \&$ teachers: $\mathrm{p}=000, \mathrm{r}=.843$ ) correlated. Likewise, the independent variable (assessment strategies) is very strong predictor of dependent variable (students' performance) because the contribution of R2 is $84.1 \%$ from students' perspective and $71.1 \%$ from teachers' perspective. Moreover, the prediction of students' performance can be made from assessment strategies because the model (F-value) for the prediction of dependent variable (students' performance) from independent variable (assessment strategies) is also significant (students: $p=000, F=2813.33$ \& teachers: $p=000, F=59.02$ ). In addition, it can be predicted that changes in dependent variable (students' performance) occur due to changes in independent variable (assessment strategies) because value of $\mathrm{t}$ (students: $\mathrm{p}=000, \mathrm{t}=53.04 \&$ teachers: $\mathrm{p}=000, \mathrm{t}=20.82$ ) is also significant.

To sum up, the result of model summary ( $\mathrm{R} \& \mathrm{R}^{2}$ ), ANNOVA and coefficient from the perspective of students and teachers for hypothesis-2 reveals that null hypothesis is rejected and alternative is upheld. Hence, it is concluded that there is significant impact of assessment strategies on students' performance in 
English. If an improvement in assessment strategies takes place, it will improve the performance of students as well.

TABLE IV. Result of hypothesis three

Hypothesis three: There is no significant impact of students' reading attitude on their performance at intermediate level.

\begin{tabular}{|c|c|c|c|c|c|c|c|c|c|}
\hline \multirow{4}{*}{$\begin{array}{l}\text { Model } \\
\text { Summary }\end{array}$} & & \multirow[t]{2}{*}{$\mathrm{R} \quad \mathrm{R}^{2}$} & \multirow{2}{*}{$\begin{array}{l}\text { Adjusted } \\
\mathrm{R}\end{array}$} & \multirow{2}{*}{$\begin{array}{l}\text { Std. } \\
\text { Error of } \\
\text { Estimate }\end{array}$} & \multicolumn{5}{|c|}{ Change Statistics } \\
\hline & \multirow[t]{2}{*}{$\begin{array}{l}\text { Students' } \\
\text { Model }\end{array}$} & & & & $\begin{array}{l}\mathrm{R} \\
\text { Square } \\
\text { Change }\end{array}$ & $\begin{array}{l}\mathrm{F} \\
\text { Change }\end{array}$ & df1 & df2 & Sig. \\
\hline & & $\begin{array}{ll}.910 & .829\end{array}$ & .828 & .42508 & .829 & 2575.463 & 1 & 533 & .00 \\
\hline & $\begin{array}{l}\text { Teachers' } \\
\text { Model }\end{array}$ & $.802 \quad .644$ & .629 & .287 & .644 & 43.410 & 1 & 24 & .00 \\
\hline \multirow[t]{7}{*}{ ANNOVA } & \multirow{4}{*}{$\begin{array}{l}\text { Students' } \\
\text { Model }\end{array}$} & & \multicolumn{2}{|c|}{ Sum of Squares } & \multicolumn{2}{|c|}{ Mean Square } & & $\mathrm{F}$ & Sig. \\
\hline & & Regression & \multicolumn{2}{|c|}{465.363} & \multicolumn{2}{|l|}{465.363} & 1 & 2575.46 & .00 \\
\hline & & Residual & \multicolumn{2}{|c|}{96.308} & \multicolumn{2}{|l|}{.181} & 533 & & \\
\hline & & Total & \multicolumn{2}{|c|}{561.671} & & & 534 & & \\
\hline & \multirow{3}{*}{$\begin{array}{l}\text { Teachers' } \\
\text { Model }\end{array}$} & Regression & \multicolumn{2}{|l|}{3.567} & \multicolumn{2}{|l|}{3.567} & 1 & 43.41 & .00 \\
\hline & & Residual & \multicolumn{2}{|l|}{1.972} & \multicolumn{2}{|l|}{.082} & 24 & & \\
\hline & & Total & \multicolumn{2}{|l|}{5.538} & & & 25 & & \\
\hline \multirow[t]{6}{*}{ Coefficient } & & & \multicolumn{2}{|c|}{$\begin{array}{l}\text { Unstandardized } \\
\text { Coefficients }\end{array}$} & & \multicolumn{2}{|c|}{$\begin{array}{l}\text { Standardized } \\
\text { Coefficients }\end{array}$} & $\mathrm{t}$ & Sig. \\
\hline & & & \multicolumn{2}{|l|}{$\mathrm{B}$} & Std. Error & \multicolumn{2}{|l|}{ Beta } & & \\
\hline & \multirow{2}{*}{$\begin{array}{l}\text { Students' } \\
\text { Model }\end{array}$} & (Constant) & \multicolumn{2}{|l|}{.908} & .055 & & & 16.652 & .00 \\
\hline & & $\begin{array}{l}\text { Reading } \\
\text { attitude }\end{array}$ & \multicolumn{2}{|l|}{.778} & .015 & \multicolumn{2}{|l|}{.910} & 50.749 & .00 \\
\hline & \multirow{2}{*}{$\begin{array}{l}\text { Teachers' } \\
\text { Model }\end{array}$} & (Constant) & \multicolumn{2}{|l|}{2.320} & .160 & & & 14.486 & .00 \\
\hline & & $\begin{array}{l}\text { Reading } \\
\text { attitude }\end{array}$ & \multicolumn{2}{|l|}{.323} & .049 & .802 & & 6.589 & .00 \\
\hline
\end{tabular}

Analysis: The result from the perspective of students and teachers as shown in table-4 reveal that there is significant impact of students' reading attitude on their performance because the independent variable (students' reading attitude) and dependent variable (students' performance) are very strongly (students: $\mathrm{p}=000, \mathrm{r}=.910$ \& teachers: $\mathrm{p}=000, \mathrm{r}=.802$ ) correlated. Likewise, the independent variable (students' reading attitude) is very strong predictor of dependent variable (students' performance) because the contribution of R2 is $82.9 \%$ from students' perspective and $64.4 \%$ from teachers' perspective. Moreover, the prediction of students' performance can be made from students' reading attitude because the model (F-value) for the prediction of dependent variable (students' performance) from independent variable (students' reading attitude) is also significant (students: $\mathrm{p}=000, \mathrm{~F}=2575.46$ \& teachers: $\mathrm{p}=000, \mathrm{~F}=43.41$ ). In addition, it can be predicted that changes in dependent variable (students' performance) occur due to changes in independent variable (students' reading attitude) because value of $t$ (students: $p=000, t=50.749 \&$ teachers: $p=000$, $\mathrm{t}=6.589)$ is also significant.

To sum up, the result of model summary ( $\& \& R^{2}$ ), ANNOVA and coefficient from the perspective of students and teachers for hypothesis-3 reveals that null hypothesis is rejected and alternative is upheld. Hence, it is concluded that there is significant impact of students' reading attitude on students' performance 
in English. If an improvement in students' reading attitude takes place, it will improve the performance of students as well.

TABLE V. Result of hypothesis four

\begin{abstract}
Hypothesis Four: There is no significant difference of perceptions between students and teachers regarding teachers' assessment strategies, teachers' teaching techniques and students' reading attitude at intermediate level.
\end{abstract}

\begin{tabular}{|c|c|c|c|c|c|c|}
\hline & & \multicolumn{5}{|c|}{ t-test for Equality of Means } \\
\hline & & $\mathrm{t}$ & Df & $\begin{array}{l}\text { Sig. (2- } \\
\text { tailed) }\end{array}$ & $\begin{array}{l}\text { Mean } \\
\text { Difference }\end{array}$ & $\begin{array}{l}\text { Std. Error } \\
\text { Difference }\end{array}$ \\
\hline \multirow{2}{*}{$\begin{array}{l}\text { Teaching } \\
\text { techniques }\end{array}$} & Equal variances assumed & 1.201 & 559 & .230 & .289 & .241 \\
\hline & $\begin{array}{l}\text { Equal variances not } \\
\text { assumed }\end{array}$ & 1.230 & 27.621 & .229 & .289 & .235 \\
\hline \multirow{2}{*}{$\begin{array}{l}\text { assessment } \\
\text { strategies }\end{array}$} & Equal variances assumed & 1.221 & 559 & .223 & .341 & .279 \\
\hline & $\begin{array}{l}\text { Equal variances not } \\
\text { assumed }\end{array}$ & 1.114 & 27.023 & .275 & .341 & .306 \\
\hline \multirow{2}{*}{$\begin{array}{l}\text { Reading } \\
\text { attitude }\end{array}$} & Equal variances assumed & 0.214 & 559 & .831 & .058 & .272 \\
\hline & $\begin{array}{l}\text { Equal variances not } \\
\text { assumed }\end{array}$ & .198 & 27.099 & .844 & .058 & .293 \\
\hline
\end{tabular}

Analysis: The insignificant result of t-test (teaching techniques: $\mathrm{p}=.230 \geq 0.05, \mathrm{t}=1.201$, assessment strategies: $\mathrm{p}=.223 \geq 0.05, \mathrm{t}=1.221 \&$ students' reading attitude: $\mathrm{p}=.831 \geq 0.05, \mathrm{t}=0.214$ ) as shown in table-5 reveals that there is no significant difference of perceptions between students and teachers regarding teachers' assessment strategies, teachers' teaching techniques and students' reading attitude at intermediate level.

To sum up, the null hypothesis is upheld because the result of t-test is insignificant. Hence, it is stated that perceptions of teachers and students regarding teachers' assessment strategies, teachers' teaching techniques and students' reading attitude are alike, having no significant difference in this regard.

Group comparison

TABLE VI. Group comparison

\begin{tabular}{|c|c|c|c|c|c|c|c|c|}
\hline & & & $\mathbf{N}$ & Mean & $\begin{array}{l}\text { Std. } \\
\text { Deviation }\end{array}$ & $\mathbf{t}$ & df. & Sig \\
\hline \multirow{2}{*}{$\begin{array}{l}\text { Performance } \\
\text { of learners }\end{array}$} & \multirow[t]{2}{*}{ Gender } & Male & 14 & 59.88 & 7.108 & \multirow[t]{2}{*}{0.879} & \multirow[t]{2}{*}{24} & \multirow[t]{2}{*}{0.388} \\
\hline & & Female & 12 & 57.32 & 7.636 & & & \\
\hline \multirow{2}{*}{$\begin{array}{l}\text { Performance } \\
\text { of learners }\end{array}$} & \multirow[t]{2}{*}{ Age } & 45 or below & 19 & 55.78 & 4.675 & \multirow[t]{2}{*}{3.880} & \multirow[t]{2}{*}{24} & \multirow[t]{2}{*}{0.001} \\
\hline & & Above 45 & 7 & 65.89 & 8.564 & & & \\
\hline \multirow{2}{*}{$\begin{array}{l}\text { Performance } \\
\text { of learners }\end{array}$} & \multirow[t]{2}{*}{ Area } & Urban & 18 & 60.64 & 7.069 & \multirow[t]{2}{*}{2.429} & \multirow[t]{2}{*}{24} & \multirow[t]{2}{*}{0.023} \\
\hline & & Rural & 8 & 53.69 & 5.843 & & & \\
\hline \multirow[t]{3}{*}{$\begin{array}{l}\text { Performance } \\
\text { of learners }\end{array}$} & Experience & $\begin{array}{l}15 \text { years or } \\
\text { below }\end{array}$ & 19 & 55.78 & 4.675 & \multirow[t]{2}{*}{3.880} & \multirow[t]{2}{*}{24} & \multirow[t]{2}{*}{0.001} \\
\hline & & Above 15 years & 7 & 65.89 & 8.564 & & & \\
\hline & Qualification & M. A, B. Ed & 8 & 52.45 & 2.253 & 3.30 & 24 & 0.003 \\
\hline
\end{tabular}




\begin{tabular}{|c|c|c|c|c|c|c|c|c|}
\hline $\begin{array}{l}\text { Performance } \\
\text { of learners }\end{array}$ & & $\begin{array}{l}\text { M.A, M. Ed \& } \\
\text { Above }\end{array}$ & 18 & 61.19 & 7.265 & & & \\
\hline \multirow[t]{2}{*}{$\begin{array}{l}\text { Performance } \\
\text { of learners }\end{array}$} & \multirow[t]{2}{*}{$\begin{array}{l}\text { Teaching } \\
\text { methods }\end{array}$} & $\begin{array}{l}\text { Two or more } \\
\text { teaching } \\
\text { methods }\end{array}$ & 11 & 64.63 & 6.357 & \multirow[t]{2}{*}{5.182} & \multirow[t]{2}{*}{24} & \multirow[t]{2}{*}{0.000} \\
\hline & & $\begin{array}{l}\text { Single teaching } \\
\text { method }\end{array}$ & 15 & 54.00 & 4.105 & & & \\
\hline \multirow[t]{2}{*}{$\begin{array}{l}\text { Performance } \\
\text { of learners }\end{array}$} & \multirow[t]{2}{*}{$\begin{array}{l}\text { Teaching } \\
\text { methods }\end{array}$} & $\begin{array}{l}\text { Translation } \\
\text { method }\end{array}$ & 17 & 62.25 & 6.199 & \multirow[t]{2}{*}{4.986} & \multirow[t]{2}{*}{24} & \multirow[t]{2}{*}{0.000} \\
\hline & & $\begin{array}{l}\text { Repeated } \\
\text { reading method }\end{array}$ & 9 & 51.42 & 2.533 & & & \\
\hline \multirow{2}{*}{$\begin{array}{l}\text { Performance } \\
\text { of learners }\end{array}$} & \multirow{2}{*}{$\begin{array}{l}\text { Use of A.V } \\
\text { aids }\end{array}$} & With A.V aids & 5 & 70.77 & 1.043 & \multirow[t]{2}{*}{7.257} & \multirow[t]{2}{*}{24} & \multirow[t]{2}{*}{.000} \\
\hline & & $\begin{array}{l}\text { Without A.V } \\
\text { aids }\end{array}$ & 21 & 55.58 & 4.584 & & & \\
\hline \multirow[t]{2}{*}{$\begin{array}{l}\text { Performance } \\
\text { of learners }\end{array}$} & \multirow[t]{2}{*}{$\begin{array}{l}\text { Teaching } \\
\text { Techniques }\end{array}$} & $\begin{array}{l}\text { Modern } \\
\text { teaching } \\
\text { techniques }\end{array}$ & 4 & 70.94 & 1.119 & \multirow[t]{2}{*}{5.30} & \multirow[t]{2}{*}{24} & \multirow[t]{2}{*}{0.000} \\
\hline & & $\begin{array}{l}\text { Traditional } \\
\text { teaching } \\
\text { techniques }\end{array}$ & 22 & 56.24 & 5.437 & & & \\
\hline \multirow[t]{2}{*}{$\begin{array}{l}\text { Performance } \\
\text { of learners }\end{array}$} & \multirow[t]{2}{*}{$\begin{array}{l}\text { Assessment } \\
\text { Test }\end{array}$} & $\begin{array}{l}\text { Objective type } \\
\text { test }\end{array}$ & 18 & 61.82 & 6.276 & \multirow[t]{2}{*}{4.678} & \multirow[t]{2}{*}{24} & \multirow[t]{2}{*}{0.000} \\
\hline & & Essay type test & 8 & 51.02 & 2.382 & & & \\
\hline \multirow{2}{*}{$\begin{array}{l}\text { Performance } \\
\text { of learners }\end{array}$} & \multirow{2}{*}{$\begin{array}{l}\text { Assessment } \\
\text { Test }\end{array}$} & Open ended & 6 & 52.05 & 1.713 & \multirow[t]{2}{*}{2.749} & \multirow[t]{2}{*}{24} & \multirow[t]{2}{*}{0.011} \\
\hline & & Close ended & 20 & 60.43 & 7.315 & & & \\
\hline \multirow[t]{2}{*}{$\begin{array}{l}\text { Performance } \\
\text { of learners }\end{array}$} & \multirow[t]{2}{*}{$\begin{array}{l}\text { Assessment } \\
\text { Test }\end{array}$} & $\begin{array}{l}\text { Multiple choice } \\
\text { tests }\end{array}$ & 18 & 61.82 & 6.276 & 4.678 & 24 & .000 \\
\hline & & $\begin{array}{l}\text { Short answer } \\
\text { tests }\end{array}$ & 8 & 51.02 & 2.382 & & & \\
\hline $\begin{array}{l}\text { Performance } \\
\text { of learners }\end{array}$ & $\begin{array}{l}\text { Assessment } \\
\text { Test }\end{array}$ & $\begin{array}{l}\text { Formative } \\
\text { summative } \\
\text { assessment }\end{array}$ & 8 & 51.02 & 2.382 & 4.68 & 24 & 0.000 \\
\hline & & $\begin{array}{l}\text { Combined } \\
\text { formative and } \\
\text { summative }\end{array}$ & 18 & 61.82 & 6.276 & & & \\
\hline Performance & Gender & Male & 237 & 60.98 & 17.850 & 3.412 & 533 & 0.001 \\
\hline oI learners & & Female & 298 & 55.53 & 18.730 & & & \\
\hline Performance & Area & Urban & 323 & 60.16 & 18.530 & 3.451 & 533 & 0.001 \\
\hline & & Rural & 212 & 54.57 & 18.049 & & & \\
\hline Performance & Class & First year & 269 & 58.11 & 18.801 & 1.497 & 533 & .210 \\
\hline or learners & & Second year & 266 & 57.77 & 18.281 & & & \\
\hline Performance & Age & 18 or below & 443 & 59.57 & 18.434 & 4.539 & 533 & .000 \\
\hline or learners & & Above 18 & 92 & 50.11 & 16.994 & & & \\
\hline
\end{tabular}




\begin{tabular}{|c|c|c|c|c|c|c|c|c|}
\hline \multirow[t]{2}{*}{$\begin{array}{l}\text { Performance } \\
\text { of learners }\end{array}$} & \multirow[t]{2}{*}{$\begin{array}{l}\text { Reading } \\
\text { activities }\end{array}$} & $\begin{array}{l}\text { participating in } \\
\text { reading }\end{array}$ & 247 & 72.12 & 10.328 & \multirow[t]{2}{*}{23.232} & \multirow[t]{2}{*}{533} & \multirow[t]{2}{*}{0.000} \\
\hline & & avoid reading & 288 & 45.78 & 15.030 & & & \\
\hline \multirow{2}{*}{$\begin{array}{l}\text { Performance } \\
\text { of learners }\end{array}$} & \multirow[t]{2}{*}{ Library } & use library & 175 & 74.49 & 9.388 & \multirow[t]{2}{*}{18.402} & \multirow[t]{2}{*}{533} & \multirow[t]{2}{*}{.000} \\
\hline & & $\begin{array}{l}\text { do not use } \\
\text { library }\end{array}$ & 360 & 49.90 & 16.417 & & & \\
\hline \multirow[t]{2}{*}{$\begin{array}{l}\text { Performance } \\
\text { of learners }\end{array}$} & \multirow[t]{2}{*}{ Books } & $\begin{array}{l}\text { Read only } \\
\text { course books }\end{array}$ & 444 & 53.44 & 16.720 & \multirow[t]{2}{*}{$-\overline{14.718}$} & \multirow[t]{2}{*}{533} & \multirow[t]{2}{*}{.000} \\
\hline & & $\begin{array}{l}\text { Read more than } \\
\text { course books }\end{array}$ & 91 & 79.92 & 8.486 & & & \\
\hline \multirow{2}{*}{$\begin{array}{l}\text { Performance } \\
\text { of learners }\end{array}$} & \multirow[t]{2}{*}{ School } & Male & 237 & 60.98 & 17.850 & \multirow[t]{2}{*}{3.412} & \multirow[t]{2}{*}{533} & \multirow[t]{2}{*}{0.001} \\
\hline & & Female & 298 & 55.53 & 18.730 & & & \\
\hline
\end{tabular}

Analysis: The result of t-test as shown in table-6 shows that:

- The teachers (both male and female) showed equal performance in their teaching practice.

- The teachers having more than 45 years age performed better than teachers with 45 years or below age.

- Urban area teachers performed better than rural area teachers.

- More experienced teachers (the teachers with more than fifteen years' experience) showed performance higher than inexperienced teachers (the teachers having experience less than fifteen years).

- The performance of teachers was directly connected with their qualification. The teachers with higher qualifications (M.A, M. Ed or above) performed better than teachers having lower qualification (M.A, B. Ed).

- Those teachers who had used multiple teaching methods in classroom teaching learning performed better than teachers who had used only one method of teaching in the classroom.

- The teachers using translation method performed better than teachers using repeated reading method.

- The teachers who used A.V. aids in the classrooms performed better than teachers who did not use A.V. aids in the classrooms.

- The teachers who used modern teaching techniques performed better than the teachers who used only traditional teaching techniques.

- The teachers who used objective type tests for the assessment of learners performed better than the teachers who used only essay type tests for the assessment of learners.

- The teachers who used close ended tests for the assessment of students performed better than the teachers who used only open ended tests for the assessment of students.

- The teachers who used multiple choice tests for the assessment of learners was better than the teachers who used only short answer tests for the assessment of students.

- The teachers who used combined formative and summative assessment in the classroom performed better than the teachers who used either formative or summative assessment in the classroom.

- The girl students' performance was higher than boy students' performance in English.

- The performance of urban area students was higher than rural area students.

- The performance of twelfth class (XII) students and eleventh class (XI) students was alike. 
- The performance of learners with an age eighteen year or below was higher than students with an age above eighteen years.

- The reading activities played a vital role in the performance of students. Those students who often participated in reading activities showed their performance higher than students who did not participate in reading activities.

- The libraries also played a vital role in the performance of students. Those students who often visited libraries for reading showed performance higher than students who did not go to libraries for reading.

- The reading more than course books also played a vital role in the performance of students. The performance of those students who used to read more than course books was higher than students who did not read more than course books.

- The male schools produced better result than female schools.

The teachers and students showed their dissatisfaction with teaching techniques applied by English teachers in their teaching. Most of the teachers did not use modern and latest teaching techniques. They taught students using centuries old traditional teaching methods. There was same teaching practice taking place daily. Teachers were incapable to teach using modern A.V aids. Moreover, teachers tried their level best to complete the course from examination view. No focus was given on basic skills of English. Rather than to make students comprehend the language, teachers preferred to have fair copies of students and motivated them to remember all the material written on fair copies like parrot. There was no systematic check and balance on teachers and students in this regard. Officers rarely visited the schools and in those visits, officer rather than to ask about the language learning skills tried to ask about the fair copies. Consequently, students used to take less interest in acquiring the basic skills of English.

The students were unable to read fluently the lengthy passages with comprehension. Their reading, spelling and vocabulary skills were very poor. They were unable to make translation of English passages into their local language. The passages were taken from their text that they had to comprehend. Additionally, the students were not able understand the grammar structure of sentences. They even were unable to differentiate between present, past and future conditional sentences.

There was no systematic assessment of both teachers and students. The schedule of assessment was present in only papers but practically there was no application of such assessment strategies. There was no system of weekly, monthly and quarterly tests. Neither internal nor external assessment was taking place in most of the institutions. Whatever the teachers used to teach and assess was the only the assessment. There was no trend of preparing progress report of students and sharing it with students, parents and other higher authorities.

Consequently, having got less motivation on the part of teachers, parents and officers, the students used to take less interest in learning basic skills of English. They tried level best to avoid participating in reading and other activities of English. Rather than to go to library, the students often used to waste their time moving to and fro, doing useless activities. Accordingly, the students showed alarmingly poor level of performance in English.

\section{Conclusion}

The independent variables (teaching techniques, assessment strategies and learners' reading attitude) were strongly correlated with the performance of learners. However, the poor performance of learners in English has raised many questions on teaching techniques, assessment strategies and learners' reading attitude. Teaching techniques and assessment strategies were centuries old and there was no use of modern teaching and assessment techniques in teaching learning of English. Moreover, due to lack of motivation, the learners did not concentrate properly on learning language skills.

\section{Suggestions}

- The result shows that effective English language learning depends more on reading, therefore, reading of English should be introduced as a separate subject along with marks equal to other subjects.

- The result shows that English teaching learning is not activity based. Hence English teaching learning should be activity based where frequent use of modern technology (A.V aids) should be ensured. 
- It appears that English teachers do not go under standardized training. Hence, English teachers should go under standardized training at least once in every year, so that they may be equipped with modern teaching and assessment techniques to enhance the performance of students in English language.

- Number of students in every English class should be 16-18. In any case they should not exceed to 20.

- The motivation of students should be kept at top priority. The problems of students taking place in school premises should be addressed on quick basis.

- The teachers should prepare and apply standardized tests in the classroom and prepare progress report of learners to acknowledge the officers, students and parents from time to time.

- The students should be given English assignments from time to time to develop their reading and research habit.

\section{REFERENCES}

Cohen, B. H. \& Lea, R. B. (2005). Essentials of Research Design and Methodology. Canada: John Wiley \& Sons, Inc.

Coleman, H. (2010). Teaching and learning in Pakistan: The role of language in education. Retrieved from http://www.britishcouncil.org/pakistan-ette-english-language-report.pdf

Creswell, J. W. (2008). Educational research: planning, conducting and evaluating quantitative and qualitative research. Columbus, Ohio: Pearson education Ltd.

Crystal, D. (1997). English as a Global language. Cambridge. Cambridge University press.

DeMarraiss, K. \& Lapan, S. D. (2004). Foundations for research methods of enquiry in education and the social science. London: Lawrence Erlbaum associates, publishers.

Erkan, G. (2005). Developing reading skills in English through strategy training at upper intermediate level in Bilkent University School of English Language (Graduate thesis). Retrieved from http://etd.lib.metu.edu.tr/upload/12606127/index.pdf

Fink, A. (1995). The Survey Handbook. Thousand Oaks, CA: Sage.

Ghani, M., Mahmood, A. \& Akram, M. (2008), measuring the performances of English language learners: A study of the learners of Punjab in Pakistan at the secondary level. Language in India, 8, 1-9. Retrieved from http://www.languageinindia.com/may2008/measuring punjabi english.pdf

Gray, D. E. (2004). Doing research in the real world. New Delhi, SAGE Publications India Pvt. Ltd.

Janjua, F., Malik, S., \& Rahman, F. (2011). Learning experiences and academic adjustment of international students: A case study from Pakistan. Journal of Language Teaching and Research, 2(6), 1359-1365. doi:10.4304/jltr.2.6.1359-1365

Kashef, S. H., Viyani, A., Ghabool, N. \& Damavand, A. (2012). Examining the effect of a learning-centered reading instruction on Iranian students' reading comprehension: An action research. English Language Teaching, 5(10), 58. doi:10.5539/elt.v5n10p58

Kasi, F. (2010). Collaborative action research: An alternative model for EFL teacher professional development in Pakistan. Asian EFL Journal, 12(3), 98- 117.

Khan, I. (2011). Reading assessment techniques among selected secondary school teachers in Pakistan: Current trends and techniques. International Journal on New Trends in Education and Their Implications, 2(4), 58-75.

Khan, I. \& Pandian, A. (2011). A proposed comprehension assessment tool for ascertaining grade 10 learner's reading performance in Pakistan. SPELT Quarterly, 26(2), 2-16.

Khan, I. \& Pandian, A. (2011). A study on reading comprehension performance in English among matriculation students in Pakistan. Modern Journal of Language Teaching Methods, 1(1), 4-14.

Nawab, A. (2012). Is it the way to teach language the way we teach language? English language teaching in rural Pakistan. Academic Research International, 2(2), 696-705

Neuman, W. L. (2007). Basics of social research: Qualitative and quantitative approaches. USA, Pearson Education Inc.

Nunan, D. (1988). Syllabus Design. Oxford. Oxford University Press. SAGE Publications. doi:10.1177/026765839000600207

Pinon, R., \& Haydon, J. (2010, December). The benefits of the English language for individuals and societies: Quantitative indicators from Cameroon, Nigeria, Rwanda, Bangladesh and Pakistan. A custom report compiled by Euro monitor International for the British Council, 1-75. Retrieved from www.euromonitor.com 
Shah, I., Farooq, S. U., Shah,T. \& Shams, M. S. (2010). A comparative study of English reading skills and socio economic factors of Pakistani universities students. International Research Journal of Finance and Economics, 47(1), 108-113. Retrieved from http://www.eurojournals.com/finance.htm

Warsi, J. (2004). Conditions under which English is taught in Pakistan: An Applied linguistic perspective. SARID Journal, 1(1), 1-9. Retrieved from http://www.saridjournal.org/2004/warsi.htms 